\title{
CHEMICAL AND MICROBIOLOGICAL EVALUATION OF SOFT WHITE CHEESE (DOMIATI CHEESE) SOLD IN KAFR EL- SHEIKH GOVERNORATE
}

\author{
E. M. I. Khalifa" and T. H. S. Badier" \\ 'Animal Health Research Institute Kafr El-Sheikh branch Food Hygiene Unit \\ "Animal Health Research Institute Kafr El-Sheikh branch Bacteriology Unit
}

\section{ABSTRACT}

A total of one hundred samples of soft white cheese (Domiati cheese) which produced by modern and primitive factories were collected from dairy shops and supermarkets in Kafr El-Sheikh and Desuq cities (25 samples each of modern and primitive factories from each city). The samples were collected aseptically in sterile polyethylene bags, placed in an insulated icebox and transferred to the laboratory with a minimum of delay. Each sample was divided into three parts, first one prepared for organoleptic inspection, the second for chemical examination while the third one taken for microbiological examination. The study revealed that all the samples examined from Kafr El-Sheikh and Desuq cities and produced from modern factories were accepted organoleptically, chemically and microbiologically, while $28 \%$ from both cities and produced from primitive factories were rejected organoleptically. Regarding the chemical analysis 52\%, $20 \%$ and 24 $\%$ of the examined samples from Kafr El-Sheikh city and 56\%, 28\% and $36 \%$ from Desuq city were rejected due to hading moisture \%, fat/ dry matter $\%$ and protein $\%$ respectively, more than the limits recommended by Egyptian standard for Domiati cheese 1008 - 3/ 2005. Concerning the microbiological examination $60 \%, 48 \%$ and $60 \%$ of the examined samples from Kafr El-Sheikh city and $72 \%$, $72 \%$ and $92 \%$ from Desuq city were rejected due to contamination with mould, yeast and coliforms counts respectively, more than the permissible limits of the aforementioned standard. Moreover, Salmonellae, Escherichia coli and Listeria monocytogenes failed to be detected from all the samples examined from both cities and produced either from modern or primitive factories. So the study prove that Domiati cheese produced from modern factories were safe for human consumption while those produced from primitive factories unsafe. Therefore, strict hygienic measures should be adopted during production of such product. 


\section{INTRODUCTION}

Cheese is universally recognized as a first class food due to its exceptional richness in high quality animal protein and milk fat. Also it is a source of calcium, phosphorus, preformed vitamin A and B2 and many micronutrients.

Domiati cheese is the most popular type of pickled soft cheese by all socioeconomic classes in Egypt due to its nutritional value, convenience and good taste. Moreover, when ripened it has strong sharp flavor as well as smooth body and texture (Kepary et al . 2007 ).

\section{(Egyptian standard for Domiati cheese 1008 - 3 / 2005) defining} the Domiati cheese as it is the fresh or ripened soft cheese which obtained after curdling the fresh milk or concentrate or mixture from its fresh or the drier products and pasteurized or treated by any thermal coefficients equivalent to pasteurization.

Although Domiati cheese production should employs the full pasteurization process there is along standing tradition of making cheese from raw milk. The tendency to reduce the heat treatment of milk is due to the believe of cheese with full ripened flavor at much shorter time and highly intensity (Metwally, 2007).

Because of raw milk utilization some preventive measures have to be taken to assure elimination of manufactured Domiati cheese from undesirable bacteria, it is usually held at least sixty days to allow a time for inactivation of pathogens during ripening process but these conditions do not cause reduction of all pathogens, so outbreaks of foodborne illness have been associated with cheese made from sub- pasteurized milk. 
The organoleptic characterization, chemical composition and the microbiological quality and safety of Domiati cheese are the major concern for both producers and consumers.

The aim of the work: In spite of popularity of Domiati cheese there were few studies on the hygienic criteria of this cheese sold in Kafr El-Sheikh governorate, so the aim of this study was to evaluate the organoleptic, chemical and microbiological characteristics of the Domiati cheese marketed in Kafr El-Sheikh and Desuq cities which produced by modern and primitive factories.

\section{MATERIAL AND METHODS}

\section{1- MATERIAL:}

A total of one hundred samples of soft white cheese (Domiati cheese) which produced by modern and primitive factories were collected from dairy shops and supermarkets in Kafr El-Sheikh and Desuq cities (25 samples each of modern and primitive factories from each city). The samples were collected aseptically in sterile polyethylene bags, placed in an insulated icebox and transferred to the laboratory with a minimum of delay. Each sample was divided into three parts, first one prepared for organoleptic inspection, the second for chemical examination while the third one taken for microbiological examination.

\section{2- METHODS:}

\subsection{Organoleptic evaluation:}

Organoleptic evaluation of Domiati cheese were evaluated according to Nelson and Trout, (1981). 


\subsection{Chemical examination:}

$\mathrm{pH}$ value was applied according to Kosikowski and Mistry, (1997) while Acidity $\%$, moisture $\%$, total solid $\%$, protein $\%$ and salt $\%$ were carried out according to the techniques recommended by $A O A C,(2003)$.

\subsection{Microbiological examination:}

\subsubsection{Preparation of samples:}

Preparation of decimal dilutions was carried out according to the technique adopted by $\boldsymbol{A P H A}$, (2003).

\subsubsection{Total mesophilic count :}

It was carried out as recommended by ICMSF, (1996).

2.3.3 Total mould, total yeast, total Enterobacteriaceae, and Coliforms count:

Were carried out by the methods adopted by APHA, (2003).

\subsubsection{Total Staphylococcus aureus count:}

It was carried out as recommended by Lancette and Tatini, (1993).

\subsubsection{Total Enterococci count:}

It was carried out by the method recommended by Efthymiou and Joseph, (1974).

2.3.6 Enumeration of presumptive Escherichia coli:

It was carried out according to ISO (1994) - 11866.

2.3.7 Detection and determination of Listeria monocytogenes:

It was carried out according to ISO (1995) - 11290.

\subsubsection{Detection of Salmonellae:}

It was carried out according to Krieg and Holt, (1986). 


\section{RESULTS AND DISCUSSION}

The organoleptic characterization of white soft cheese includes (packaging, flavor "taste and odor", body texture, appearance and color are considered the most important factors for evaluation. Their sum is very helpful in emerge the possible defects that may be found in the product. In addition most people accept and consume cheese principally for its organoleptic qualities.

From the summarized data given in table (1) it is evident that the minimum, maximum and mean value of the overall acceptability of the examined samples collected from Kafr El-Sheikh and Desuq cities and produced from modern factories were $90 \%, 100 \%, 95.8 \% \pm 0.6,88.5 \%$, $99.5 \%$ and $95.4 \% \pm 0.7$ respectively, while those produced from primitive factories were $86 \%, 98 \% 91.7 \% \pm 0.8,85 \%, 97 \%$ and $90.7 \% \pm 0.8$ respectively, meanwhile the results represented in table (2) revealed that the highest frequency distribution of the examined samples collected from modern factories in Kafr El-Sheikh city were $20 \%$ and 64 $\%$ lied within the grade excellent and good respectively, while $16 \%$ lied within the grade fair and no samples lied within the grade poor, also nearly the same results were obtained in samples collected from Desuq city and produced from modern factories where, the highest frequency distribution were $24 \%$ and $60 \%$ lied within the grade excellent and good respectively, but $16 \%$ lied within the grade fair and no sample lied within the grade poor which may be attributed to using high quality milk and implementing good manufacturing practices. Nearly similar results were obtained by (Abeer et al . 2006). On the other hand, the highest frequency distribution of the examined samples collected from primitive factories in Kafr El-Sheikh city were $40 \%$ and $32 \%$ lied within the grade 
good and fair respectively, while $28 \%$ lied within the grade poor and no sample lied within the grade excellent. Nearly the same findings were recorded in samples collected from Desuq city and produced from primitive factories where, the highest frequency distribution lied within the grade good and fair (36\% of each) and $28 \%$ lied within the grade poor while no sample lied within the grade excellent which may be attributed to using milk of low quality and applying primitive technique with neglected hygienic measures. Nearly similar findings were recorded by ( El- Kotry et al. 1992 ).

The composition of Domiati cheese falls within certain compositional range (Egyptian standard for Domiati cheese 1008 - 3 / 2005), the most important compositional factors are fat in dry matter (F/DM)\%, moisture $\%$, salt $\%$, protein $\%$, acidity $\%$ and $\mathrm{pH}$ value, as all aspects of cheese curd production (rennet coagulation, gel firmness) are affected by chemical composition of the cheese milk especially the concentration of casein, calcium and $\mathrm{pH}$ (Fox and Me Sweeney, 2003).

The presented data in tables ( $3 \& 4$ ) shows that the chemical composition of the samples produced from modern factories collected from both Kafr El- Sheikh and Desuq cities nearly similar to each other where the mean value of $\mathrm{pH}$, acidity $\%$, moisture $\%$, fat $\%$, total solid $\%$, fat / dry matter $\%$, protein $\%$ and salt $\%$ of samples collected from Kafr El- Sheikh city were $6.08 \pm 0.03,0.34 \pm 0.01,58.69 \pm 0.15,18.96 \pm$ $0.13,41.31 \pm 0.15,45.90 \pm 0.25,10.55 \pm 0.03$ and $8.22 \pm 0.09$ respectively, while those collected from Desuq city were $6.18 \pm 0.03$, $0.37 \pm 0.01,59.49 \pm 0.68,19.05 \pm 0.13,41.23 \pm 0.15,46.24 \pm 0.25,10.46$ \pm 0.03 and $8.11 \pm 0.09$ respectively. On the other hand, the samples collected from both cities and produced from primitive factories also nearly show the same results where the mean value of $\mathrm{pH}$, acidity $\%$, moisture 
$\%$, fat $\%$, total solid $\%$, fat / dry matter $\%$, protein $\%$ and salt $\%$ of samples collected from Kafr El- Sheikh city were $5.35 \pm 0.12,0.69 \pm$ $0.07,61.32 \pm 0.64,16.82 \pm 0.52,38.68 \pm 0.64,43.30 \pm 0.68,9.69 \pm 0.18$ and $8.44 \pm 0.07$ respectively, while those collected from Desuq city were $5.37 \pm 0.12,0.70 \pm 0.07,62.32 \pm 0.64,19.00 \pm 0.53,37.68 \pm 0.64,42.51$ $\pm 0.70,9.17 \pm 0.19$ and $8.15 \pm 0.20$ respectively. Nearly similar findings for samples from modern factories were reported by (Abeer et al. 2006), while the results obtained from primitive factories were in good agreement with those reported by (Salwa et al. 2007). On the other hand, the study revealed that the samples from primitive factories had lower $\mathrm{pH}$ value and higher titratable acidity than those from modern factories and this may be attributed to the high microbial content of samples and greater utilization of lactic acid leading to low $\mathrm{pH}$ value and higher titratable acidity. While the samples from modern factories contained low bacterial content owing to the effect of pasteurization (Ghosh et al. 1999). The results summarized in tables $(3 \& 4)$ shows that the samples examined from both cities and produced from primitive factories had relatively lower fat $\%$, total solids $\%$, protein $\%$ and salt $\%$ than those samples collected from both cities and produced from modern factories which may be attributed to higher moisture content. Nearly similar findings were reported by (Salwa and Galal, 2002). According to (Egyptian standard for Domiati cheese 1008 - 3 / 2005) which stated that, moisture content must not higher $60 \%$, salt content must be within $9 \%$, protein should be within $10 \%$ and the ratio of fat on dry matter must be $45 \%$ and less than $60 \%$, all the samples examined which produced from modern factories of two cities lied within the permissible limits of the standard, while 52\%, $20 \%$ and $24 \%$ of samples collected from Kafr El- Sheikh city, 56\%, $28 \%$ and $36 \%$ from Desuq city which produced from primitive factories were rejected due to containing moisture $\%$, fat $/$ dry matter $\%$ and protein $\%$ respectively higher than the permissible limits. 
The microbial quality and safety of Domiati cheese is the major area of concern for producers and consumers. It depends on the types of microorganisms introduced from raw milk, efficiency of processing and the hygienic practice applied in dairy plant. Handling of milk during cheese manufacture plays an important role in the proliferation of microbial flora and consequently impair its utility and render the product unfit for human consumption (Sveum et al . 1992, Yousef et al. 2001 and Leuschner and Boughtflower, 2002).

Egyptian standard for Domiati cheese 1008 - 3 / 2005) stipulated that, Domiati cheese should be free from pathogenic microorganisms and their toxins, Escherichia coli, Listeria monocytogenes or any visible mould growths. Moreover, total coliforms count, total mould count, total yeast count should not exceed 10, 10, and $400 \mathrm{CFU} / \mathrm{g}$. respectively.

From the obtained results in tables $(5 \& 6)$ it is evident that all the samples examined from both cities and produced from modern factories shows nearly similar positive samples and microbial count, where the incidence of positive samples and mean value of total (bacterial, mould, yeast, coliforms,Enterobacteriacae Staphylococcus aureus and Enterococci) count of samples collected from Kafr El- Sheikh city were 25 (100\%), $1.1 \times 10^{3} \pm 1.9 \times 10^{2}, 10(40 \%), 7.2 \pm 0.5,15(60 \%), 1.6 \times 10^{2} \pm 1.7 \times 10$, $3(12 \%), 0.9 \times 10 \pm 0.4,5(20 \%), 2.3 \times 10 \pm 0.24 \times 10,3(12 \%), 5.3 \times$ $10^{2} \pm 9 \times 10$, and $2(8 \%), 2.6 \times 10^{2} \pm 4.6 \times 10 \mathrm{CFU} / \mathrm{g}$. respectively, while those collected from Desuq city were $25(100 \%), 1.1 \times 10^{3} \pm 2.0 \times$ $10^{2}, 12(48 \%), 8.3 \pm 1.2,16(64 \%), 1.9 \times 10^{2} \pm 1.9 \times 10,2(8 \%), 1.4 \times 10$ $\pm 0.2,6(24 \%), 2.7 \times 10 \pm 0.32 \times 10,5(20 \%), 9 \times 10^{2} \pm 9.9 \times 10$, and 3 (12\%), $3.5 \times 10^{2} \pm 5.6 \times 10 \mathrm{CFU} / \mathrm{g}$. respectively. Also the results obtained from examination of the samples collected from both cities and 
produced from primitive factories nearly similar to each other where the incidence of positive samples and mean value of total (bacterial, mould, yeast, coliforms, Enterobacteriacae Staphylococcus aureus and Enterococci) count of samples collected from Kafr El- Sheikh city were 25 (100\%), $3.9 \times 10^{4} \pm 1.6 \times 10^{4}, 18(72 \%), 5.4 \times 10 \pm 0.62 \times 10,20(80 \%), 5.3 \times 10^{2}$ $\pm 0.62 \times 10,25(100 \%), 8.6 \times 10 \pm 4.6 \times 10,25(100 \%), 1.7 \times 10^{3} \pm 6.9 \times$ $10^{2}, 20(80 \%), 2.5 \times 10^{3} \pm 5.8 \times 10^{2}$, and $18(72 \%), 1.8 \times 10^{3} \pm 5.1 \times 10^{2}$ CFU / g. respectively. while those examined from Desuq city were 25 $(100 \%), 4.4 \times 10^{4} \pm 2.0 \times 10^{4}, 19(76 \%), 6.6 \times 10 \pm 0.61 \times 10,22(88 \%)$, $6.1 \times 10^{2} \pm 4.4 \times 10,25(100 \%), 1.6 \times 10^{2} \pm 9.5 \times 10,25(100 \%), 1.2 \times$ $10^{3} \pm 5.9 \times 10^{2}, 22(88 \%), 3.0 \times 10^{3} \pm 6.6 \times 10^{2}$, and $20(80 \%), 2.2 \times 10^{3} \pm$ $5.7 \times 10^{2} \mathrm{CFU} / \mathrm{g}$. respectively. From the results that previously mentioned and according to Egyptian standard for Domiati cheese 1008 - 3 / 2005) all the samples examined from both cities and produced from modern factories lied within the accepted limits which could be attributed to good manufacturing practices and efficient pasteurization process against the selected microbial groups, while more than $50 \%$ of the samples collected from both cities and produced from primitive factories did not met the standard, where $60 \%, 48 \%$ and $60 \%$ of the samples which collected from Kafr El- Sheikh city and $72 \%, 72 \%$ and $92 \%$ of the samples collected from Desuq city contaminated with total mould count, total yeast count and total coliforms count respectively, more than the permissible limits of the standard which may be due to deeply neglected the manufacturing practices and hygienic measures along the production line. Nearly similar results for samples from modern factories were reported by (Riadh, 2005 and Omer and Osman, 2007) while nearly similar findings to samples from primitive factories were recorded by (Abd EL-Shaheed, 2004 and Abeer et al. 2006). 
Furthermore, it could be seen from the results recorded in tables ( 5 $\& 6)$ that the samples examined from Desuq city and produced from primitive factories contaminated with mould and yeast more than those from Kafr El- Sheikh city, which may be attributed to the numerous sources of cheese contamination. It may be contaminated through milk used, washing water, environment, utensils and equipments, as well as through persons taking part in manufacturing and handling the product (Mace et al. 2004 and Mullan, 2007). The public health importance of moulds has been emphasized as certain species can produce mycotoxins, which may induce food poisoning among consumers.

Also it could be noticed from the results reported in tables $(5 \& 6)$ that, the samples examined from Desuq city and produced from primitive factories were highly contaminated with coliforms from those examined from Kafr El- Sheikh city which may be due to production of milk and cheese under poor conditions (Ceylan et al.2003 and Warsama et al.2006). Coliforms count are traditional indicator of possible faecal contamination , microbial quality and wholesomeness and reflect the hygienic standards adopted in the dairy processing (Ozdemir et al . 1998).

Moreover, Escherichia coli, Listeria monocytogenes and Salmonellae were not found in all samples examined from both cities either produced from modern or primitive factories probably due to high levels of salt.

Generally, the results of this work declared that, the cheese which produced from modern factories are safe for human consumption where all the samples examined from both cities were lied within the limits stated by Egyptian standard for Domiati cheese 1008 - 3 / 2005). While those produced from primitive factories were unsafe where $28 \%$ of the samples collected from both cities were rejected organoleptically while $20 \%, 24 \%$ and $52 \%$ of samples examined from Kafr El- Sheikh city and $28 \%, 36 \%$ and $56 \%$ from Desuq city containing fat / dry matter \%, 
protein $\%$ and moisture $\%$ respectively more than the permissible limits of Egyptian standard. Concerning the microbiological examination $60 \%$, $48 \%$ and $60 \%$ of samples examined from Kafr El- Sheikh city and $72 \%$, $72 \%$ and $92 \%$ from Desuq city contaminated with mould, yeast and coliforms counts respectively more than the accepted limits of the aforementioned standard. So we can not depend on the organoletic and chemical examination alone on judging on the hygienic quality of Domiati cheese.

Finally, Hazard Analysis Critical Control Point (HACCP) system is the suitable precaution procedures should be carefully implemented in the manufacture of Domiati cheese depending on the determined critical control point(s) (CCPs) to produce safe and high quality product.

Table (1): Statistical analytical results of total organoleptic inspection of the examined Domiati cheese samples collected from Kafr El-Sheikh and Desuq cities.

\begin{tabular}{|c|c|c|c|c|}
\hline \multirow{2}{*}{ Items } & \multicolumn{2}{|c|}{ Factories at Kafr El-Sheikh city } & \multicolumn{2}{|c|}{ Factories at Desuq city } \\
\hline & Modern factories & Primitive factories & Modern factories & Primitive factories \\
\hline No. of samples & 25 & 25 & 25 & 25 \\
\hline Minimum & 90 & 86 & 88.5 & 85 \\
\hline Maximum & 100 & 98 & 99.5 & 97 \\
\hline Mean & 95.8 & 91.7 & 95.4 & 90.7 \\
\hline \pm SEM & 0.6 & 0.8 & 0.7 & 0.8 \\
\hline
\end{tabular}

Table (2): Frequency distribution of the overall acceptability of the examined Domiaticheese samples collected from Kafr El- Sheikh and Desuq cities.

\begin{tabular}{|c|c|c|c|c|c|c|c|c|c|}
\hline \multirow{3}{*}{ Intervals } & \multirow{3}{*}{ Grading } & \multicolumn{4}{|c|}{ Factories at Kafr El-Sheikh city } & \multicolumn{4}{|c|}{ Factories at Desuq city } \\
\hline & & \multicolumn{2}{|c|}{\begin{tabular}{|c|} 
Modern factories \\
Frequency
\end{tabular}} & \multicolumn{2}{|c|}{\begin{tabular}{|c|} 
Primitive factories \\
Frequency
\end{tabular}} & \multicolumn{2}{|c|}{\begin{tabular}{|c|} 
Modern factories \\
Frequency
\end{tabular}} & \multicolumn{2}{|c|}{$\begin{array}{c}\text { Primitive factorie } \\
\text { Frequency }\end{array}$} \\
\hline & & $\begin{array}{l}\text { No. of } \\
\text { samples }\end{array}$ & $\%$ & $\begin{array}{c}\text { No. of } \\
\text { samples }\end{array}$ & $\%$ & \begin{tabular}{|c|} 
No. of \\
samples
\end{tabular} & $\%$ & \begin{tabular}{|c|} 
No. of \\
samples
\end{tabular} & $\%$ \\
\hline 98.5-100 & $\overline{\text { Excellent }}$ & 5 & 20 & 0 & 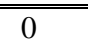 & 6 & 24 & 0 & $\overline{00}$ \\
\hline $94-98.5$ & Good & 16 & 64 & 10 & 40 & 15 & 60 & 9 & 36 \\
\hline $88.5-92.5$ & Fair & 4 & 16 & 8 & 32 & 4 & 16 & 9 & 36 \\
\hline $\begin{array}{c}87.5 \text { or } \\
\text { less }\end{array}$ & Poor & 0 & 0 & 7 & 28 & 0 & 0 & 7 & 28 \\
\hline
\end{tabular}

Kafrelsheikh Vet. Med. J. Vol. 7 No. 1 (2009) 


\section{REFERENCES}

- Abd El-Shaheed, Y. S. Y. (2004): Assessment the hygienic status of two white Damietta cheese in Alexandria Governorate through their products. Fourth Scientific Vet. Med. Conference, Oct . 2-4, Alex . Vet. J. Vol . 21(2):574-584.

- Abeer, A. Abdel All; Saudi, A. M.; Moawad, A. A. (2006): Microbiological and compositional status of Egyptian white soft cheese J. Egypt. Vet. Med. Assoc. Vol. 66 No. 3: 25-25.

- American Public Health Association APHA (APHA) (2003): Compendium of methods for the Micribiological Examination of Foods $3^{\text {rd }}$ Ed. (Vanderzant, C. and Splittoesser, D. eds) Washington, D. C. USA, p. $675-800$.

- Association of Official Analytical Chemists (AOAC) (2003): Official analytical chemists. $15^{\text {th }}$ Ed.; Inc. Arlington, Virginia, USA.

- Ceylan,Z.G., Turkoglu and Dayisoylu, (2003): The microbiological and chemical quality of Skima cheese produced in Turkey . Pak . J . of Nut . 2 ( 2 ) : 95-97.

- Efthymiou, C. J. Joseph, S. w. (1974): Development of a selective enterococcus medium based on manganese ion deficiency, sodium azide and alkaline PH . Appl . Microbiol ., 28 : 411-416.

- Egyptian Organization of Standardization and Quality Control (1008-3 /2005) : Egyptian standard of white soft cheese (Domiati cheese) . 
- El- Kotry, R.; Nassib, T.; El- Gazzar, H. and Shehata, A. (1992): Use of certain bacteria extra - cellular enzyme fractions in the manufacture of Domiati cheese and its effect on its yield, chemical and organoleptic properties. Proceeding : $5^{\text {th }}$ Egyptian conference for dairy science and technology, 145-157

- Fox, P. E. and MeSweeney, P. L. (2003): Advanced dairy chemistry, Vol . 1, Proteins . Kluwer Academic / Plenum Publishers, New York.

- Ghosh, B. A.; Steel and H. Kessler, (1999): Effect of heat treat and homogenization of milk on camembert cheese. Egyptian J. Dairy Sci., $27: 331-343$.

- International Commission of Microbiological Specifications for Foods ICMSF (1996): International Commission of Microbiological Specifications for Foods: Microorganisms in Food. Vol. 1 Their Significance and methods of enumeration $2^{\text {nd }}$ Ed., Univ. Toronto, press Toronto and Buffalo Canada .

- International Organization for Standardization (ISO) (1994): Milk and milk products. Enumeration of Presumptive Escherichia coli . ISO / DIS, 11866.

- International Organization for Standardization (ISO) (1995): Horizontal method for the detection and enumeration of Listeria monocytogenes .ISO / DIS ,11290-1.

- Kepary, M.; Kamaly, K.; Zedan, N. and Zaghlol, A. (2007): Acceleration of ripening of Domiati cheese by accelase and lipozyme enzyme . Egyptian Journal of Dairy Science 35 ( 1 ) : 75-90 . 
- Kosikowski, F. V. and Mistry, V. V. (1997): Cheese and Fermented Milk Foods, Vol . 2: Procedure and analysis $3^{\text {rd }}$ ed. (Kosikowski, F. V. Ed) USA, Academic Press, p 268-299.

- Krieg, N.and Holt,J.(1986): Berge's Manual of Systemic Bacteriology. Vol. 2 USA.

- Lancette, G. and Tatini, S. (1993): Staph . aureus Compendium of Methods for the Microbiological Examination of Foods . INC $4^{\text {th }}$ Ed.; New York . Vanderzantic, C . and Splittistoesser, D . F .

- Leuschner, R. and M. Boughtflower, (2002): Laboratory scale preparation of soft cheese artificially contaminated with low levels o Escherichia coli O 157, Listeria monocytogenes, and Salmonella enterica Serovars Typhimurium, Enteritidis, and Dublin . J . Food Protect . $65: 508-514$.

- Mace, J. O.; Javanovic, S. and Barac, M. (2004): The influence of different kinds of milk on quality of cheese. J. Biotechnol. 20 (2): 109-117.

- Metwally, B. N. (2007): Hygienic quality of soft cheese marketed in Cairo .M ,. V . Sc. Fac. Vet. Med . Cairo Univeristy .

- Mullan, W. M . (2007): Classification of cheese types using calcium and PH . J . Dairy Sci . and Food Technol . 28 ( 4 ) : 200-209 .

- Nelson, J. A. and Trout, G. M. (1981): Judjing of dairy products, $4^{\text {th }}$ ed . INC Westport, Academic Press , 345-567.

- Omer, I. A. and Osman, A. O. (2007): Microbiological properties and sensory characteristics of white cheese (gibna bada) collected in Zalingei area, West Darfur state . Research Journal of Animal and Vet. Sci . 2 : 61-65. 
- Ozdemir, S.; Celik, C. and Sert, M. (1998): The microbiological and chemical properties of orgu cheese produced in Karacadag region of Diyarbakir, Turkey . In National Productivity Center Publ . No . 66 .

- Riadh Al - Tahiri (2005): Acomparison on microbial conditions between traditional dairy products sold in Kark and same products produced by modern dairies Pakistan J . of Nutrition 4 ( 5 ) : 345-348.

- Salwa, A. Aly and Galal, E. A. (2002): Effect of milk pretreatment on the keeping quality of Domiati cheese. Pakistan J. of Nutrition 1 (3): $132-136$.

- Salwa, A. Aly; Morgan, S. D; and Moawad, A. A. (2007): Effect of moisture, salt content and $\mathrm{PH}$ on the microbiological quality of traditional Egyptian Domiati cheese . Assiut Vet . Med . J . 53(115 ) : $68-81$.

- Sveum, W. L. Moberg, R. Rude and J. Frank, (1992): Microbiological monitoring of the food processing environment . Chapter 3 .

- Warasma, L. M., Ibtisam. E. M. El Zubir and O. A. O. El Owni, (2006): Composition and hygienic quality of Sudanese soft cheese in Khartoum North (Sudan). Intl. J. Dairy Science, 1 (1): 36-43 .

- Yousef, H. M. Sobieh and K. Nagedan, (2001): Microbial status of Domiati cheese at Al Gassiem area Saudi Arabia . $8^{\text {th }}$ Sci . Con . Fac . Vet . Med . Assiut Univ . p; 91-97 . 
التقييي الكيميائي واليكروبيولوجى للجبن الابيض الطرى (الجبن الدمياطى)

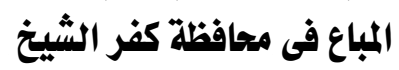

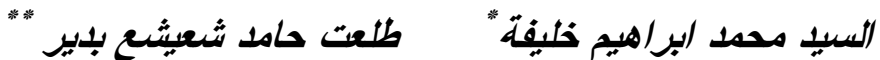

معهز بحوث صحة الحيوان - المعمل الفرعى بكفر الثيخ" وحدة صحة الأغذية معهز بحوث صحة الحيوان - المعمل الفرعى بكفر الثيخ" وحدة البكتيريولوجى

تم تجميع عدد 100 عينة من الجبن الابيض الطرى (الجبن الدمياطى) و المباع فى مدينتى كفر

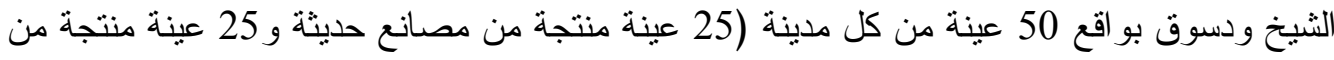

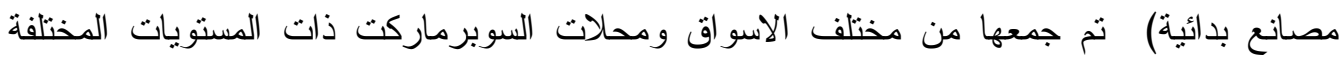
بهاتين المدينتين وتم نقل هذه العينات مباثرة الى المعمل دون ابطاء حيث نم اجراء الاختبارات

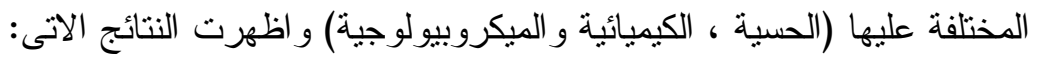

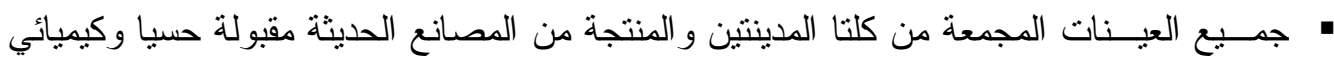

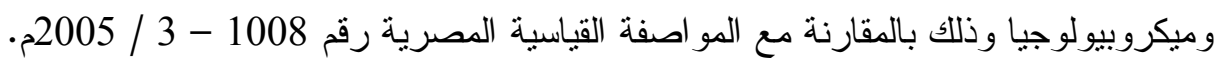

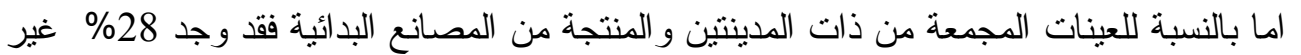

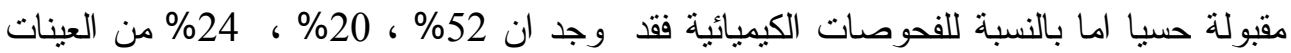

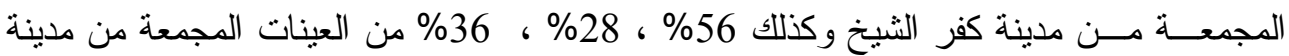

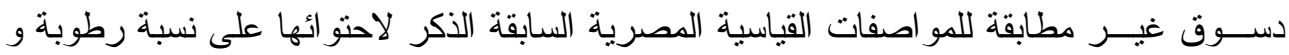

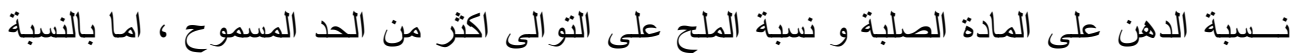
للفحوصات الميكروبيولوجية فقد وجد ان 60\% و 48\% و 60\% من من العينات المجمعة من مدينة

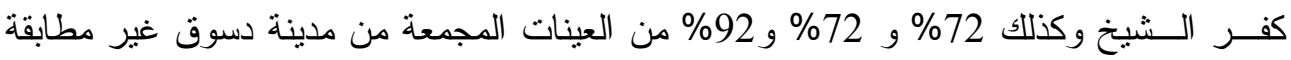
لللو اصــفات القياسية المصرية لاحتو ائها على فطريات وخمائر وكوليفورم على التو الى اكثر من

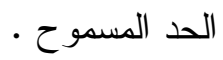

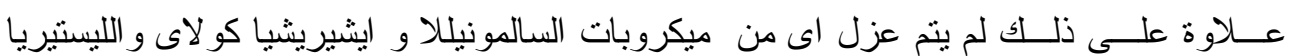

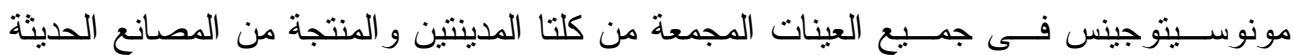
و البدائية . مان.

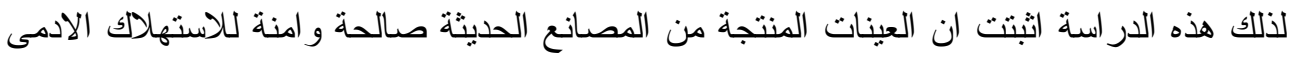

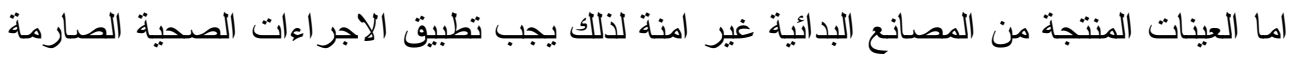

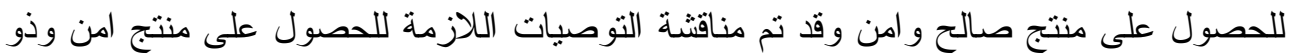

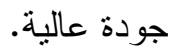

